\title{
FOREIGN LANGUAGE COMPETENCY LEVELS IN MILITARY EDUCATION
}

\section{Roliak Angelina ${ }^{1}$}

DOI: https://doi.org/10.30525/978-9934-571-89-3_22

Modern development of the foreign language component in any professional environment (including military) leads to the necessity of modernization in the general approach of foreign language proficiency levels and their standardization. Graduates from different educational institutions of today must be able to achieve the best results and comfort in their professional activity in a very short period of time. So it is necessary to expand such important for every profession concepts of "knowledge", "abilities" and "skills" with the additional categories. The notion of "competence" is such category which can enrich the abovementioned concepts with the practical side of their implementation [1, p. 147]. Pointing out that today military systems of all the European countries are on the way of transition to the competence model of development it is very important to examine and analyze European experience of general competence scheme adoption and use in language proficiency sphere.

Considering STANAG 6001 as NATO Standardization Agreement (NSA), which has been ratified by nations as reflected in the NATO Standardization Document Database (NSDD), we shall outline the circle of important foreign language proficiency or competence levels provided for NATO Forces and give the guidance for the language programme content on their mastering, developing and using in practical activities. In this study we judge the terms "language proficiency" and "competence" as evaluative ones denoting an individual's spontaneous, general language communication ability [3, p. 73; 4].

Our research demonstrates that STANAG 6001 gives the detailed definitions of the competence levels in four common language proficiency skills: "listening", "speaking", "reading" and "writing". The North Atlantic Treaty Organization (NATO) developed these levels to define the general English proficiency (nonmilitary specific) of military personnel.

According to STANAG 6001 six language competence levels are analyzed, identifying each skill area in the following way:

Level 0 - No proficiency

Level 1 - Survival

Level 2 - Functional

Level 3 - Professional

Level 4 - Expert

Level 5 - Highly-articulate native [4].

At the same time, STANAG states quite clearly that language training and testing is a national responsibility of every state [4]. So NATO does not require nations to

${ }^{1}$ State Agrarian and Engineering University in Podilya, Ukraine 
follow a standardized curriculum. Each nation must develop its own tests to comply to a common standard.

All of six language proficiency levels are described in details by STANAG 6001 documents. But it is important to point out that the European Working Group believes that Level 3 is the highest level of language needed for most requirements of military occupations. So for military education in Ukraine only three levels (first, second and third) are relevant. That is why, they are of special importance in our research. Moreover our investigation demonstrates that Military English courses in Germany, Italy, Poland, Hungary, Romania, Denmark and Finland are developed according to NATO's STANAG language profile and are also offered at 3 levels, represented in table 1.

Table 1

\section{Language Competence Levels}

\begin{tabular}{|c|c|}
\hline \multicolumn{2}{|l|}{ Level 1} \\
\hline Listening & $\begin{array}{l}\text { Can understand common familiar phrases and short simple sentences } \\
\text { about everyday personal and survival needs. }\end{array}$ \\
\hline Speaking & $\begin{array}{l}\text { Can maintain simple face-to-face communication in typical everyday } \\
\text { situations. }\end{array}$ \\
\hline Reading & $\begin{array}{l}\text { Can read very simple connected written material directly related to } \\
\text { everyday survival or workplace situations. }\end{array}$ \\
\hline Writing & $\begin{array}{l}\text { Can write lists, short notes, phone messages to meet immediate personal } \\
\text { needs. Can complete forms. }\end{array}$ \\
\hline \multicolumn{2}{|l|}{ Level 2} \\
\hline Listening & $\begin{array}{l}\text { Can follow conversations and talks about everyday topics, including } \\
\text { personal news, well-known current events and routine job-related topics } \\
\text { and topics in his/her professional field. }\end{array}$ \\
\hline Speaking & Can communicate in everyday social and routine workplace situations. \\
\hline Reading & Can read simple, straightforward, factual texts on familiar topics. \\
\hline Writing & $\begin{array}{l}\text { Can write with some precision simple personal correspondence and routine } \\
\text { workplace correspondence and related documents, including brief reports. }\end{array}$ \\
\hline \multicolumn{2}{|r|}{ 1 1} \\
\hline Listening & $\begin{array}{l}\text { Can understand conversations, briefings and telephone calls about } \\
\text { complex topics, including economics, science, technology and his/her } \\
\text { own professional field. }\end{array}$ \\
\hline Speaking & $\begin{array}{l}\text { Can participate effectively in most formal \& informal conversations, } \\
\text { including meetings. Can deliver briefings. }\end{array}$ \\
\hline Reading & $\begin{array}{l}\text { Read with almost complete comprehension a variety of authentic written } \\
\text { material on general and professional subjects, including unfamiliar } \\
\text { subject matter. }\end{array}$ \\
\hline Writing & $\begin{array}{l}\text { Can write effective formal and informal correspondence and other } \\
\text { documents on practical, social and professional topics and special fields } \\
\text { of competence. }\end{array}$ \\
\hline
\end{tabular}


This part of the paper is centered on a brief analysis of these levels focusing on speaking activities, since the ability to communicate is considered to be the most complex competence combining in itself the appropriate grammar, listening and comprehension skills [5, p. 147]:

Level 1 is aimed at beginners. The first level is approximately equivalent to the Council of Europe's A2 - Waystage. It is often called the "Survival" or "Elementary". Military students at this level should be able to maintain simple face-to-face communication in typical everyday situations; create with the language by combining and recombining familiar, learned elements of speech; begin, maintain, and close short conversations. Their speaking activities cannot be characterized by natural fluency. Nonetheless as the basic users, they can speak at the simple sentence level. Pronunciation, vocabulary, and grammar errors may often cause misunderstanding [2, p. 184].

Level 2 is equivalent to the Council of Europe's B1 - Threshold. The second level is called "Functional" or "Fair (Limited Working)". Military students at this level should be ready to handle most normal, casual, simple conversations topics regarding their everyday social and routine workplace situations. As the independent users they can give complicated, detailed, and extensive directions and instructions, to discus projects within very familiar subject-matter fields. Meaning is accurately expressed in simple sentences. Complex grammar structures are often avoided. Pronunciation, vocabulary, and grammar errors may sometimes occur [2, p. 184].

Level 3 is approximately equivalent to the Council of Europe's B2 - Vantage. The third level is "Professional". Military students at this level should possess lexical vocabulary adequate for all practical and social conversations and for professional discussions in a known field so they should be able to participate effectively in most formal and informal conversations; discuss particular interests and special fields of competence with considerable ease. They are expected to demonstrate language competence when conducting meetings, delivering briefings or other extended and elaborate monologues, hypothesizing, and dealing with unfamiliar subjects and situations [2, p. 184]. According to ALTE (Association of Language Testers in Europe) scale, this level is upper intermediate so military students can produce extended conversations and convey their ideas correctly and effectively.

Our study shows that language proficiency levels were adopted by participating in NSA nations with the aim of:

- generalization of communicating language requirements for international staff appointments;

- coverage and recording measures of language proficiency in international correspondence;

- through a standardized approach comparing national standards while preserving each nation's right to maintain its own internal proficiency standards [4].

From the point of view of the Ukrainian Army development all these language competences form the basis of efficient professional activity of a serviceman in a new knowledge-based century. Modern Ukrainian Army needs specialists with high level of foreign language proficiency. 
This research extends our understanding of the fact that foreign language competence improvement can lead out Ukrainian military specialists to the qualitatively new level, bringing them more opportunities of acquiring and changing of knowledge, information and experience within the European and global world environment.

\section{References:}

1. Ogienko O., Rolyak A. (2009, May). Model of Professional Teachers Competences Formation: European Dimension. Teacher Education Policy in Europe (TEPE) Network, pp. 147-157.

2. Rebrii I.M. (2017). English Teaching Faculty Development Workshop: International Experience and Prospects for Ukraine. Visnyk HNU. Inozemna Philologiia, vol. 86, pp. 182-188.

3. Roliak A.O. (2018). Reforms in teacher education system: Danish experience in Ukrainian environment. Humanities and Social Sciences in Europe: Achievements and Perspectives. The 1st International symposium proceedings. (Berlin, January 25, 2018), Berlin: Premier Publishing s.r.o., pp. 70-78.

4. STANAG 6001 (Edition 4). (2010). Language Proficiency Levels. Retrieved from: http://mod.gov.rs/stanag/srpski_stanag_6001/STANAG\%206001\%20Edt.\%204\%20LANGUAGEPROFICIE NCY\%20LEVELS.pdf (accessed 10 March 2019).

5. Roliak A.O. (2011). Profesiina pidgotovka vchyteliv u vyshchyh navchalnyh zakladah Danii [Teachers Professional Training in High Educational Institutions of Denmark] (PhD Thesis), Kyiv: Institute of Pedagogic Education and Adult Education of NAPS of Ukraine. 